\title{
Employee Engagement and Organizational Survival
}

\author{
C.S. Biriowu, Ofurum Ugonna Augustina
}

\begin{abstract}
Talented and motivated employees are vital in the survival of any organization. In a turbulence and competitive environment, employee engagement has been shown to be the source of competitive advantage. The paper examined the association of employee engagement and organizational survival, with organizational culture as the moderating variable. The paper is a theoretical review of extant literature on employee engagement, organizational culture and organizational survival. To achieve its objectives, the paper adopted teamwork, empowerment and participation as the dimensions of employee engagement while innovativeness, adaptability and situation awareness were chosen as the measures of organizational survival. The finding of paper showed that when employees were given the power to participate in the decision making, they feel valued, trusted and will go beyond the demands of the job and ensure that organizationalgoals are accomplished. However, the paper also found that effective leadership, communication, reward, recognition and atmosphere of fairness among others are the drivers of engagement. The paper concluded that employee engagement predicts organizational survival, whileorganizational culture influences both variables. The paper recommended that managers should keep their employees engaged in order to reduce cost of recruiting new employees for the same job. In addition, since organizational culture influencesemployee engagement, management of organizations should ensure that employee engagement is crafted into their strategic intent in order to have engaged employees that will help the organization achieve its goals. Lastly, organization can utilize the exit interview with departing employees to determine the level of engagement in the organization if properly handled.
\end{abstract}

Index Terms - Employee Engagement, Organizational Survival, Organizational Culture, Participation, Teamwork, Empowerment, Situation Awareness, Innovativeness and Adaptability.

\section{INTRODUCTION}

Contemporary organizations are faced with array of complexities, coupled with the dynamic nature of business environment, as well as the effect of globalization at the workplace. These complexities are sometimes within and outside the control of managers or organizational leaders. Organizations interact with both internal and external environments, and these environments influence their existence. Thus, organizations are social systems that interact to achieve predetermined goals such as: survival, goodwill, good citizenship, profitability, improved market share among others (Jaja, Gabriel and Wobodo, 2019). Organizational survival reinforces all other objectives, its achievement adds

C.S. Biriowu, Ph.D, Department of Management, Faculty of Management Sciences, Rivers State University, Port Harcourt, Rivers State, Nigeria Ofurum Ugonna Augustina, Department of Management, Rivers State University, Port Harcourt, Nigeria to the fulfillment and application of other organizational objectives (Gross, 1968). This implies that survival is very crucial and remains one of the key objectives of any organization, without which the business will go into extinction.

Osborne and Hammoud (2017) posit that corporate survival is dependent on maximizing profits from existing competences; and achieved through dedicated and motivated employees who influence the success of any organization (Laila, Iqbal and Rasheed, 2019). Buttressing this view, Kortmann, Gelhard, Zimmermann and Piller (2014) opined that managers or organizational leaders must ensure the engagement of dedicated and motivated employees that will work diligently towards achieving and sustaining profitability. To achieve this, managers are devising strategies to improve performance and ensure survival amidst all the disturbances encountered in the organization. The responsibility of achieving competitive advantage does not rest on the managers or leaders alone, but with the employees (Olughor and Oke, 2014). According to Aguinis (2013), human beings are vital to the success of any business; and this is accomplished through motivated and talented employees who render excellent service to customers. Therefore, efforts should be made in getting them engaged and drawing necessary inputs in the advantage of the organization.

Employee engagement describes a situation where employees feel involved, committed, passionate, empowered and these feelings are exhibited in the work behavior (Mone and London, 2010). This means that employee engagement involves the level of commitment, participation and teamwork displayed by employees towards the organization. Employee engagement has been a subject of attraction for almost two decades (Albercht, Bakker, Gruman, Macey and Saks, 2015); and in recent years, it has been echoed strongly with business executives (Macey, Schneider, Barbera and Young, 2009). Additionally, organizations believe that engagement is a main source of competitive advantage. Therefore, the impact of employee engagement cannot be overemphasized. It has been shown to influence a range of attitudinal, behavioural, performance, and financial outcomes (Christian, Garza and Slaughter, 2011; Halbesleben, 2010; Macey et al., 2009). Halbesleben (2010) meta-analysis revealed that engagement is positively linked with commitment, health, turnover intention and performance. Thus, it is an approach that increases the probability of business success, beneficial to both individual and organization, as well as improves productivity and well-being of employees.

Moreover, it has become widely used in human resource management (HRM) domain. This is because it covers other concepts that other commonly used terms like motivation, satisfaction and commitment do not manage very well 
(Torrington, Hall, Taylor and Atkinson, 2014). It was observed that during economic downturn, that engaged employees were instrumental in achieving competitive edge and subsequent survival or success of business organization (Richman, 2006). In the present-day work environment, employee engagement has evolved as perhaps the best challenge in the light of complexities and serves as strict guidelines in many organizations (Mishra, Boynton and Mishra, 2014).The process by which we expect engagement to happen needs to be fully understood so that managers can adopt strategies or manage other contextual issues to enable full employee engagement.

As observed by Pepra-Mensah and Kyeremeh (2018), it is not easy to drive and encourage high levels of engagement among employees in organization. The responsibility lies on the organization and their managers to adopt appropriate strategies that will encourage engagement. Organizational characteristics such as culture can influence it, as well as lead to organizational survival. Scholars posit that culture is one of the approaches to drive engagement among employees (Namrita and Yoginder, 2017; Alarcon, Lyons and Tartaglia, 2010). Culture is the way of life of people and affects the way individuals think, feel, act and behave in anorganization. Therefore, an organization with positive and strong culture can control the behaviour of a highly motivated and dedicated employee while a negative and weak culture will affect the employee negatively (Pepra-Mensah and Kyeremeh, 2018). Hence, employee engagement is the result of a well-established organizational culture (Denison, 2010 cited in Pepra-Mensah and Kyeremeh, 2018).Despite the conceptualization of employee engagement by Kahn (1990), there is paucity of both theoretical and empirical literature on the influence of employee engagement on organizational survival. Against this backdrop, this paper critically reviewed the concept of employee engagement and organizational survival. To achieve its objectives, teamwork, participation and empowerment were the dimensions of employee engagement while innovativeness, adaptability and situation awareness were the measures of organizational survival. It will also, review somedefinitions;identify some of the drivers, outcomes and measurements of employee engagementas well as the theoretical framework linking the two variables.
Conceptual Framework of Employee Engagement and Organizational Survival

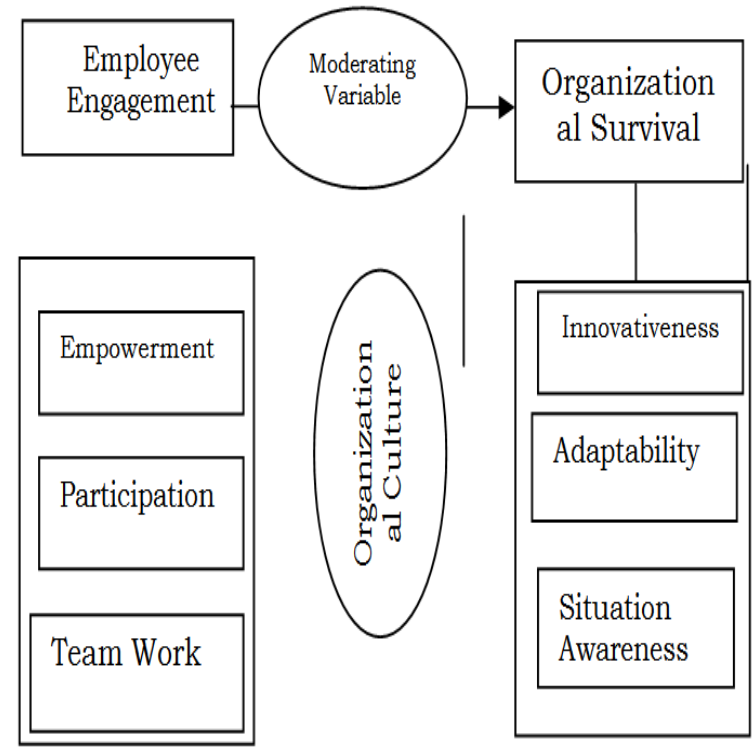

Fig 1: Conceptual Framework of Employee Engagement and Organizational Survival.

Source: Conceptualized by the Researcher, 2020.

Theoretical Framework of Employee Engagement and OrganizationalSurvival

Social exchange theory and organizational justice are the theories linking both variables.

\section{Social EXCHANGe THEORY}

This theory postulates that social behavior is the result of an exchange process (Blau, 1964). According to social exchange theory, when employees receive value through empowerment, training, and participation, the employees will feelsense of belonging and in return will reciprocate the gesture or repay the organization by being engaged physically, emotionally and cognitively. The employees will become motivated to perform their job as well as bring in creative ideas and innovativeness to turn the fortune of the business around. Additionally, engaged employees are basis of creative performance, and this will attract more talented individuals to the organization. When talented individuals are attracted they will become a source of competitive edge for the organization, hence an asset, not a liability like disengaged employee. Employee engagement is based on giving and giving more, with the belief that the gesture will be reciprocated. Consequently, when they are empowered to take decision concerning them, they will become more committed to the success of the organization.

\section{Organizational Justice Theory}

The emphasis of this theory is on how leaders use fairness in the procedure that results to outcome (Colquitt, Conlon, Wesson, Porter and $\mathrm{Ng}, 2001$ ). This outcome must be perceived to be fair by everybody in the organization. Thus, procedural justice predicts employee engagement. Equity or fairness is a key driver of employee engagement, while the 
key elements are commitment and discretionary effort. Saks (2006) argued that employee engagement is linked with a sustainable workload, feelings of choice and control, appropriate recognition and reward, a supportive work community, fairness and justice, and meaningful and valued work. An atmosphere of fairness tries to make the employees' place of work better. When an organization treats its employees well, in return they will be dedicated to their job and become physically and emotional committed to the organization. According to Frank, Finnegan and Taylor (2004), employee engagement drives employee's aspiration and willingness to give discretionary efforts in their jobs. When an employee's give discretionary efforts in their job, they will work above their job demands to ensure the organization achieves its goals. Consequently, when an organization achieves its predetermined goals, the organization has been able to adapt to changes in the environment as well as competitive edge.

\section{EMPLOYEE ENGAGEMENT}

The development originated from the studies conducted in the 1920s on morale or a group's enthusiasm to achieve organizational goals, and used by the US Army scholars during World War II to forecast unity of effort and attitudinal battle, in order to get prepared before they confront their opponent (Siddhanta and Roy, 2010).Conversely, Torrington et al. (2014) averred that employee engagement is credited to the work of Khan (1990), who postulated the first grounded theory concerningpersonal engagement and disengagement at workplace.Thus, it was after this conceptualization, that employee engagement came into limelight. With respect to its definition and measurement, there has been divergence ofviews among scholars and practitioners. It has been defined differently by scholars and practitioners. Torrington et al.(2014) observed the lack of clear, precise, concise and widely agreed definition of engagement. This they attributed partly to the sheer number of different ways in which the verb 'to engage' is defined in dictionaries and commonly used in everyday speech.

Moreover, the lack of agreed definition is a limitation for researchers to reach a better understanding of how to measure it. Thus, employee engagement has been defined and measured differently by researchers and consultants, however, the meaning sound like other constructs like organizational citizenship behaviour and organizational commitment (Robinson, Perryman and Hayday, 2004). Consequently, researchers, practitioners and reviewers do not use the same components to describe employee engagement.Thus, there is no universally agreed definition and measurement, but has common elements such as: energy, involvement and an inclination to contribute to organizational success (Bakker, Albrecht and Leiter, 2011).Employee engagement is defined as "the harnessing of organization members' selves to their work roles; in engagement, people employ and express themselves physically, cognitively, and emotionally during role performances"(Kahn, 1990: 694). This is an all-encompassing definition that has three aspects of engagement: physical, cognitive and emotional.The physical aspect centers on the physical vitalities exerted by individuals to achieve their roles. The cognitive concerns the belief of the employees' about the organization, the leaders and working conditions. The emotional aspect concerns the feelings employees' have about each of the factors and its effects, which could lead to positive or negative attitudes towards theorganization and its leaders. This implies that engagement entails psychological and physical presence of employees when carrying out tasks in an organization.Similarly, Schaufeli, Salanova, González-Romá and Bakker (2002:74) describe employee engagement "as a positive, fulfilling, work-related state of mind that is characterized by vigor, dedication, and absorption".Vigor is described by high levels of energy and mental resilience, dedication depicts feelings of importance, passion, inspiration, pride and challenges while absorption involves being dedicated and occupied with the job and not thinking of quitting the job.

According to Abraham (2012), employee engagement is the degree to which the employees are satisfied with their job. In the same vein, Mone and London (2010) see employee engagement as asituation where employees feel involved, committed, passionate, empowered and these feelings are exhibited in the work behavior. By implication, employee engagement is the level of commitment and participation an employee displays towards the organization. Also, Markos and Sridevi (2010) advanced that employee engagement has positive influence on organizational performance. They further opined that when employees are more engaged, theorganization performs better and, thus has a positive impact on performance outcomes such as productivity, profitability, employee retention, safety and customer loyalty. From the above definitions, we can deduce two elements of employee engagement as commitment and discretionary effort.Thus, this paper adopts the definition of employee engagement by Mone and London (2010), and from where thedimensions (teamwork, participation and empowerment) were derived.

Equally, there is a decrease in employee engagement, as well as heightened disengagement among employees today. Notwithstanding the numerous research and coupled with the huge number of surveys that organizations can utilize in measuring it, engagement has relatively remained unchanged. Gallup (2006) identified three levels of engagement : (i) engaged employees who are those that are full of vitality and enthusiastic about their job ;(ii) not engaged employees who are investing their effort and approaching their work with little vitality or enthusiasm, yet not meddling with others;(iii) disengaged employees and involve those individuals who are miserable about their work, and who effectively mumble and gripe about their job and the organization, as well as subvert what their engaged colleagues are attempting to accomplish.According to Reilly (2014), thesurvey conducted by Gallup showed that only $13 \%$ of the global employees were engaged. However, the recent report of Gallup on the condition of the worldwide workforce, granting that the outcomes improved for Hopkins University in the 2018 survey, employee engagement is still not impressive. The 
report of the most recent condition of the worldwide working environment shows that $85 \%$ of employees are not engrossed or effectively disengaged at the workplace. Specifically, Gallup stated that $18 \%$ are effectively detached at work, while $67 \%$ are not locked in at all and they don't have any intention of leaving the organization (HR Exchange Network, 2018). This implies that organization will record low rates of employee turnover but have high level of disengagement.

\section{Drivers of Employee Engagement}

Employee engagement drivers are those factors that facilitate job satisfaction.They are those things that when present in an organization, can make employees to go beyond their job demand and ensure the organization survives. From the review of extant literature, scholars have advanced several drivers of engagement, but below are the eight factors that we deduce from the extant literature that can drive engagement. Effective leadership affects employee engagement. A leader has a role to play in driving employee engagement. According to Reilly (2014), leaders and supervisors ought to inspire employee participation by identifying the obstructions to engagement as well as appreciate any solutions emanating from the employees in order to effect positive change.

Thus, Fig 2 below highlights the major drivers of engagement and when implemented by managers will cause the employees to be dedicated and work towards attaining goals and organizational survival.

\section{The Drivers of Employee Engagement}

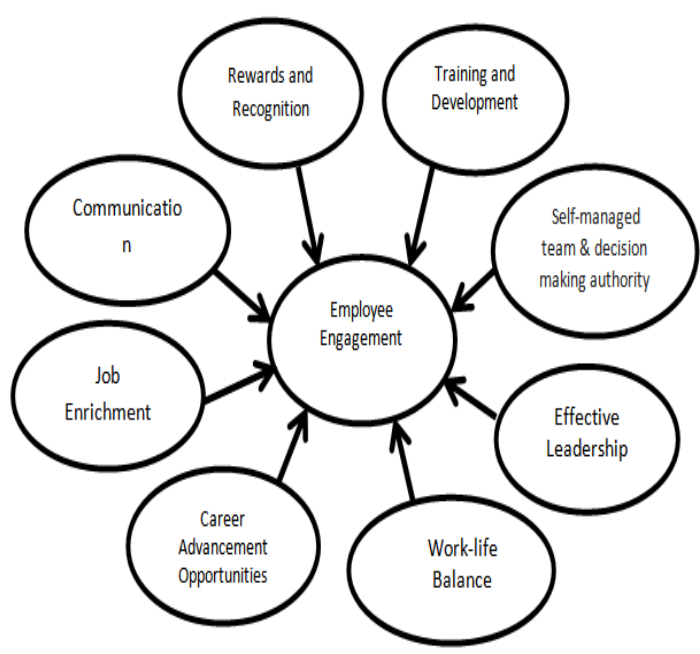

Figure 2: The Drivers of Employee Engagement Source: Conceptualized by the Researcher, 2020

\section{Measurement of Employee Engagement}

According to Chartered Institute of Personnel Management of Nigeria (CIPM, 2018), an organization may use a survey to ascertain employee engagement at intervals. But, the employees may not see anything positive of the survey. As such organizations spend huge sums of money in private research on engagement, which the employees view as unfriendly activity. Employee engagement consists of cognitive, emotional and behaviourial components, and measurement of employee engagement should generally contain questions that focus on these three components. Therefore, questions on cognitive component evaluateemployee's beliefs about the organization, its leaders, and the prevalent culture in that organization.The emotional questions measure employee's feelings about the organization and their work. Such questions will include their satisfaction on the job, recognition and rewards received from the organization among others. The behavioural questions assess the amount of effort employees are willing to apply as well as their readiness to exhibit extra-role behaviours and commitment to remain in the organization.From the perspective of AIHR Analytics (2019), there are challenges encountered in measuring of employee engagement. They identified lack of unified definition as the biggest challenge. Consequently, they identified three ways to measure employee engagement as (i) by an employee engagement survey provider; (ii) the organization; and (iii) hybrid approach in which annual engagement is measured by the survey provider while pulse engagement is measured by the company throughout the year.The service provider is the method that is traditionally used by many organizations, and is estimated each a couple of years. The provider deals with the coordination and the software while the outcomes of the study are conveyed to the organization. Gallup and Mercer are the renowned survey providers. These approaches have merits and demerits, the demerits range from costly to time consuming; while the hybrid approach involves analytics and has been used by many companies for over two decades (AIHR Analytics, 2019).

They further posit that organizations use employee feedback form for particular divisions with the yearly evaluation, and used for specific analyses, which include: assessment of sales performance and analyzing the motives behind truancy in a particular unit. Pulse survey is also a technique used by many organizations, which involves set of questions sent to chosen workforce to get understanding about the organization.Thus, measuring employee engagement is a big challenge but advised the use of pre-validated survey and engagement of the services of a psychometriciantodesign the questionnaire for the survey. However, they recommended science based research like Utrecht work engagement scale (UWES) and Gallup work audit. Figure 3 depicts an employee pulse survey while figure 4 is a Gallup workplace audit.

\section{An Employee Pulse Survey}




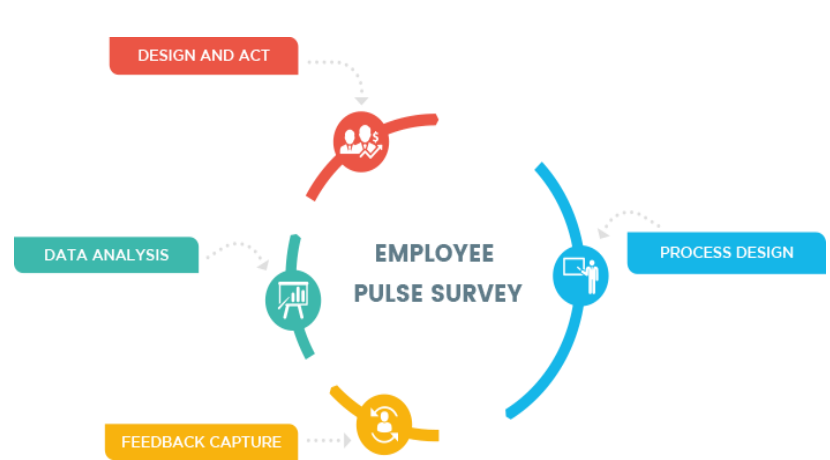

Fig 3: Employee Pulse Survey

Source: AIHR Analytics, 2019.

\section{Measuring Employee Engagement Metrics}

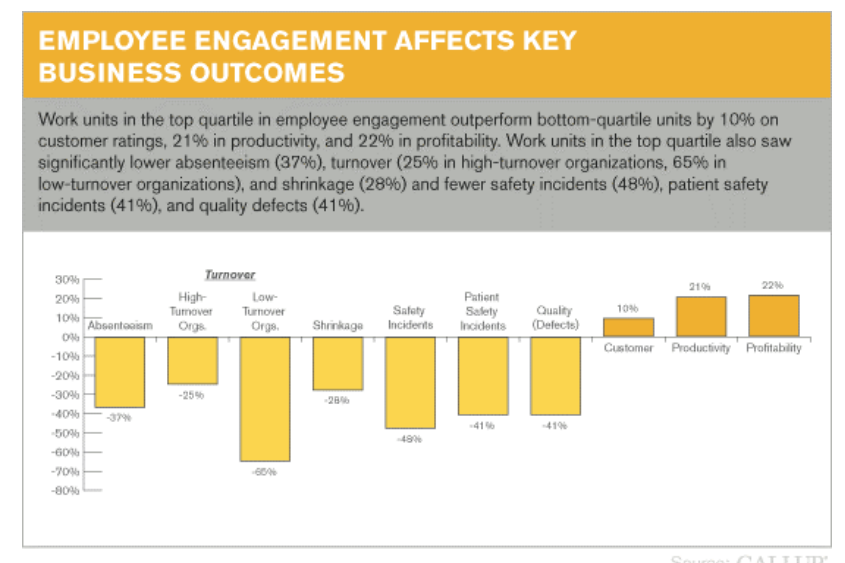

Fig 4: Gallup workplace Audit

Source: Gallup

\section{Outcomes of Employee Engagement}

Employee engagement is vital for organizational success, and influences employee and financial performance. Engaged employees feel valued, trusted and thus perform above their job tasks to achieve organizational goals. Table 1 shows some of the outcomes of employee engagement.

Table 1: Outcomes of Employee Engagement

\begin{tabular}{|c|l|l|l|}
\hline S/N & Individual Outcomes & Team/ Unit Outcomes & Organizational Outcomes \\
\hline 1 & PositiveAttitudes to work & Team Performance & Improved Performance \\
\hline 2 & Job satisfaction & Team Innovation & Improved Productivity \\
\hline 3 & Commitment and Motivation & Team cohesiveness & Competitive Advantage \\
\hline 4 & Reduced turnover intentions & Group Think & Financial Returns \\
\hline 5 & $\begin{array}{c}\text { Performance/Behaviour(in-role } \\
\text { behaviour and extra-role behaviour) }\end{array}$ & & Retention \\
\hline 6 & Reduced Absenteeism & & $\begin{array}{l}\text { Enhanced Customer Service } \\
\text { Improved Quality } \\
\text { Organizational Success }\end{array}$ \\
\hline
\end{tabular}

\section{Source: Conceptualized by the Researcher, 2020}

\section{Dimensions of Employee Engagement}

Empowerment: Employee empowerment is seen as a profitable venture that yield return for organization. This is because of their skills, knowledge and experience which represent economic value thereby enhancing productivity. Given the highly competitive business environment, many top managers believe that giving up centralized control will promote speed, flexibility, and decisiveness in employees' actions (Draft, 2001).Pastor (1996) describes empowerment as employee's ability to make decisions and take responsibility for their own actions. According to Saif and
Saleh (2013), empowermentis an approach of giving an employee the authority to make decisions and the allocation of responsibilities from manager to other employees. Baird and Wang (2010) defineemployee empowerment as the delegation of power and responsibility occupied by management level in the organizational hierarchy to lower level employees, with respect to decision making. According to Senevirathna, (2018), the aim of empowerment is to improve the performance of employees by increasing participation and involvement in decision making.Hunjra, UlHaq, Akbar and Yousaf (2011) posit that empowerment is a fundamental and important concept for achieving success, productivity, and growth in any businessendeavor. In the view of Meyerson and Dewettinck (2012), it involves the development of trust, motivation, participating in 
decisionmaking, as well as the removal of any boundaries between an employee and top management. Studies conducted by scholars showed that empowerment has various outcomes on organization, such as: achievement of success, employee performance, job satisfaction (Meyerson and Dewettinck, 2012; Raza, Mahmood, Owais and Raza, 2015).

Teamwork:In today's business environment, it is only few employees that can perform their job without the support and input of others. Thus, when employees have the support and cooperation of their colleagues, they will share innovative ideas, accomplish more tasks, and proffer creative solutions to complex problems experienced in their organization. Ancona and Caldwell (1992) opined that organization depend on teams for the development of innovative products and services. Teamwork plays an important role in the accomplishment of tasks in organization, and aids in reducing organizational hierarchy and increases the involvement of employees.Teams are needed in all organizations, be it hospital, oil rigs, military, flight decks and in all other organizations that functions on a daily basis (Salas, Shuffler, Thayer, Bedwell and Lazzara, 2014).

Teams are "distinguishable set of two or more people who interact, dynamically, interdependently, and adaptively towards a common and valued goal/objective/mission" (Salas, Dickinson, Converse and Tannenbaum, 1992: 4). Marks, Mathieu and Zaccaro (2000) defined teamwork as individuals who work interdependently towards achieving a common goal.Teamwork is the adaptive, dynamic, and intermittent process that comprises the thoughts, feelings, and behaviors among team members in their interaction towards attaining a common goal (Salas et al., 2014). Burke, Wilson and Salas (2003) posit that to achieve effectiveness among teams, they must successfully perform both task work and teamwork. Task work entails the completion of specific tasks by team members in order to achieve team goals. Mathieu, Maynard, Rapp and Gilson (2008) averred that effective teamwork entails the sharing of knowledge, coordinating behaviours, and trusting one another, if these are not feasible, they will fail. This implies that both task work and team work are crucial for team to perform successfully and the effectiveness of one assists the other.Salas et al. (2014) after reviewing some research on teamworkdeveloped a heuristic guideline known as "critical considerations." These nine critical considerations start with the letter $\mathrm{C}$ and is adapted but with some modification with respect to the meanings and references.

Table 2: The 9 Critical Considerations of Teamwork

\begin{tabular}{|c|c|c|}
\hline Critical Considerations & Meanings & References \\
\hline Cooperation & $\begin{array}{l}\text { These are behaviourial action that } \\
\text { drives teamwork and include: attitudes, } \\
\text { beliefs, and feelings of the team } \\
\text { members. }\end{array}$ & $\begin{array}{l}\text { Mathieu, Maynard, Rapp \& Gilson } \\
\text { (2008). }\end{array}$ \\
\hline Conflict & $\begin{array}{l}\text { The alleged incompatibilities in the } \\
\text { interests and beliefs held by one or more } \\
\text { team members. }\end{array}$ & $\begin{array}{l}\text { Bradley, Postlethwaite, } \\
\text { Hamdani \&Brown (2011). }\end{array}$ \\
\hline Coordination & $\begin{array}{l}\text { The organizing of complex activities } \\
\text { to enable them work together to achieve } \\
\text { results. }\end{array}$ & $\begin{array}{l}\text { Marks, Zaccaro \& Mathieu } \\
\text { (2001). }\end{array}$ \\
\hline Communication & $\begin{array}{l}\text { The process whereby information are } \\
\text { disseminated to members of a team. The } \\
\text { feedback will form and recreates the } \\
\text { attitudes, behaviors, and cognitions of } \\
\text { the team. }\end{array}$ & $\begin{array}{l}\text { Connaughton \& Daly, 2004; LePine, } \\
\text { piccolo, Jackson, Mathieu \& Saul } \\
(2008) \text {. }\end{array}$ \\
\hline Coaching & $\begin{array}{l}\text { This is a form of development in } \\
\text { which a person called "A Coach" } \\
\text { supports a learner in achieving a specific } \\
\text { career goal by providing training, advice } \\
\text { and guidance. }\end{array}$ & $\begin{array}{c}\text { Hackman \& Wageman, 2005; } \\
\text { Morgeson, DeRue, \& Karam (2010). }\end{array}$ \\
\hline Cognition & $\begin{array}{l}\text { The mental process of acquiring } \\
\text { knowledge, skill, abilities and } \\
\text { understanding through thoughts, } \\
\text { experience and the senses which is } \\
\text { shared among team members. }\end{array}$ & DeChurch \& MesmerMagnus, (2010). \\
\hline
\end{tabular}




\begin{tabular}{|c|c|c|}
\hline Composition & $\begin{array}{l}\text { This entails the competence of a good } \\
\text { team such the expertise, abilities, and } \\
\text { mindsets, as well as the effect of } \\
\text { diversity in achieving success in the } \\
\text { team. }\end{array}$ & $\begin{array}{l}\text { Humphrey, Morgeson, \& Mannor } \\
\text { (2009). }\end{array}$ \\
\hline Context & $\begin{array}{l}\text { This means situational attributes } \\
\text { which influence the event, behaviors and } \\
\text { how the different factors impact on team } \\
\text { results. }\end{array}$ & $\begin{array}{l}\text { Bedwell, Wildman, DiazGranados, } \\
\text { Salazar, Kramer \& Salas (2012); Hertel, } \\
\text { Konradt \& Orlikowski (2004). }\end{array}$ \\
\hline Culture & $\begin{array}{l}\text { The way of life of the people that } \\
\text { determines how individual think, feel, } \\
\text { and perform their tasks, and visible in } \\
\text { their values, beliefs, norms, and artifacts. }\end{array}$ & $\begin{array}{l}\text { Stahl, Maznevski, Voigt \& Jonsen } \\
\text { (2010). }\end{array}$ \\
\hline
\end{tabular}

Source: Adapted from Salas, Shuffler, Thayer, Bedwell, and Lazzara(2014).

Participation: This is one of the key concepts

in communication and media studies. Employee involvement in decision making is also referred to as participative decision-making (PDM). It is a process by which employees are involved in the organizational decision making in which they work. Vroom (1974) defined participation simply as involvement. In the view ofNoah (2008), participation is a special type of delegation whereby the subordinate gain greater control as well as freedom of choice aimed at linking the communication gap between the management and employees. Similarly, Mitchell (1973) describes it as situation where decision making isshared in the work environment.Kim (2002)has argued that participative decision making is an essential element that improves job satisfaction in an organization.

Additionally, Cotton, Vollrath, Froggatt, Lengnick-Hall and Jennings (1988) contendedthe existence of strong relationship between organizational and individual effectiveness. Thus, managers in organization must treat their employees fairly, in order to achieve organizationalgoals (Irawanto, 2015).Moreover, scholars have carried out studies on employee participation and other variables that influence it. The study carried out by Cadwallader, Jarvis, Bitner and Ostrom (2010) revealed that a number of elements control the link between the participation of the employees in decision-making with organizational climate, including efficient cooperation and effective dissemination of information amongst others. When employees are allowed to take decision in an organization, they feel valued, secured and communicates freely with their peers without limits and formal courses of action.

The study carried out by Wood and De Menezes (2011) align with the above view, as their findings revealed that when employees take part in any decision making program introduced in organization, itincreases their motivation.
Employees' involvement in decision making has several outcomes such as: increase motivation (Kim, 2002); increase workers satisfaction (Cotton et al., 1988); improves job satisfaction (Kim, 2002); organizational performance (Kazimoto, 2016); and innovation (Senevirathna, 2018) among others. In essence, performance in organizations can be enhancedby giving the employees the opportunity to share their thoughts and emotions (Kazimoto, 2016).Furthermore, Markos and Sridevi (2010) averred that for employees to achieve expected results, organizations should allow them to be independent on their job, thereby reassuring independent reasoning,critical thinking, and in taking feasible decision on the best way to complete theirresponsibilities. They further advanced that managers and leaders should attend to employees' concerns and recognize their contributions, as this will improve organizational performance. Davis and Newstrom (1997)posit that in certain circumstances,participation will link with mental and emotional involvement thereby resulting to increase in employee motivation. This will also lead tojob satisfaction,effective teamwork, improved supervision,reduced stress, less conflict, as well as enhanced commitment to organization goals and acceptance of organizational change. They conceptualized employee participation process as shown in fig 5 below. 


\section{Employee Participation Process}

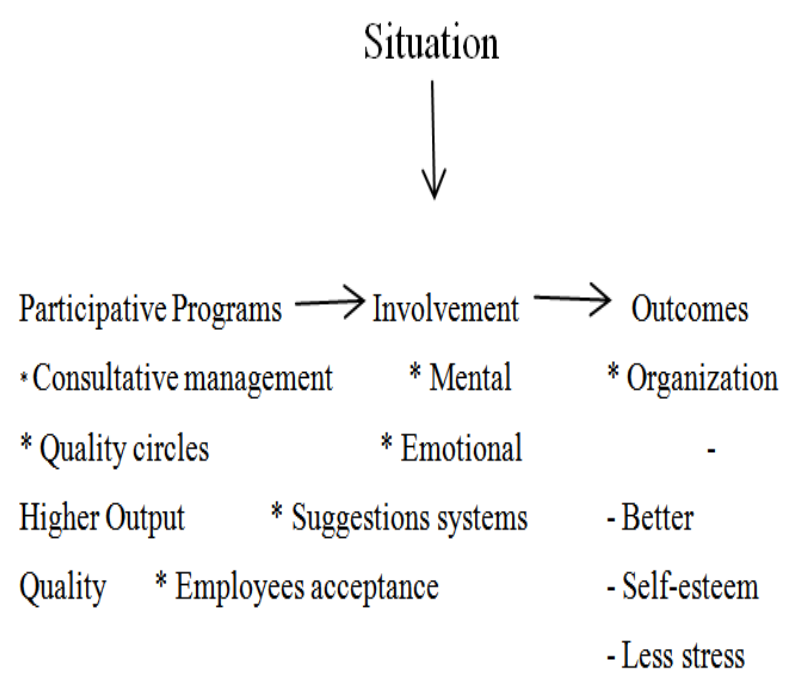

Fig 5:EmployeeParticipation Process Source:Davis and Newstrom (1997).

\section{ORGANIZATIONAL SURVIVAL}

Organizational survival is dependent on its capability to muddle through the influence of internal and external environmental factors. External environmental factors such as political, socio-cultural, economic, legal among other affects the survival of any business.Organizational survival strengthens every other objectives of any organization, and isseen as an unwritten law of every organization (Gross, 1968). In addition, Gross (1968) posit that any organization that does not have survival as their primary objective should reassess the objectives. According to Sheppard (1993), the most objective approach in measuring survival in organizations is to observe their continuing existence. From the perspective of Lee (2006), forany organization to survive in a competitive and vibrant business environment, depends on how effective the organization learn to adapt itself to the environment, as well as take advantage of its human and material resources. In the same light, Huber (2011) stated that adapting to changing environments remains a serious concern for organizational leaders if they must survive. This implies that for any organization to achieve survivability, the leaders must have adaptive capacity and must keep abreast of environmental factors affecting their organization. This they can do, by constantly scanning the environment.

Innovativeness: This is anorganization-wide innovation capability structure, and is the defining factor for long term survival of firms. In innovation and tourism literature, the word innovativeness has been frequently used, however with a blend of conceptualizations and understandings, as often as possible utilized conversely with innovation (Wang and Ahmed, 2004).Literature reveals that innovativeness is anantecedent to innovation and denotes a firm's ability to innovate (Hult, Hurley and Knight, 2004). This implies that innovativeness is planned and viable alignment of a company while Manu (1992) posit that innovation is the means adopted by organization in accomplishing competitive advantage.In corroborating with the above view, Menguc and Auh (2006) see innovativeness as a means to an end and not an end.They further posit that this is what differentiates innovativeness from innovation.

Innovativeness has been defined differently by scholars. It is defined as a "firm's overall innovative capability of introducing new products to the market, or opening up new markets, through combining strategic orientation with innovative behaviour and process" (Wang and Ahmed 2004: 304). On the other hand, Slater and Narver (1994) consider innovativeness to be one of the basic belief making competences that drive performance. Reasoning in the same line of thought, Markides (1998) sees it to be the improvement of newviable plans that create value for the organization. Amabile (1977) associates it with organizational creativity. In the view of Hult et al. (2004) innovativeness is seen as the ability of firm's to introduce new processes, products, or ideas in the organization. In the same vein, Lumpkin and Dess (1996) describe it as a company's proclivity to take part in and bolster new thoughts, to explore, and be inventive. From the above definitions, creativity is considered a key element of innovativeness. Consequently, in a competitive global marketplace, innovativeness helps organizations to achieve competitive edge. It also contributes to increased competitiveness and supportsthe likelihoods of survival (Ellonen, Blomqvist and Puumalainen, 2008).Therefore, innovation helps organization to remain competitive and attain sustainability.

Adaptability: The development of the word adaptability is traced to the field of biology, and it means the ability to be flexible when change occurs (Akhigbe and Ohiria, 2017). According to Denison (2017), it is the extent to which an organization has the capacity to modify behavior, structures; and systems geared towards survival during environmental change. It is considered to mean the active changing of the business operating environment. From the perspective of Cohen and Levinthal (1990), adaptability is the ability of an organization to expect and simultaneously react to threats and opportunities by controlling the circumstance to its advantage.It is a continuous process of change that lasts throughout the organization.Organization is an open system that constantly interacts with the environment.

According to Agboola and Salawu (2011: 235), "organizations have to adapt to the environment to become competitive and stay ahead or at least keep afloat". Therefore, the employees have to adjust to both internal and external conditions such as: revision of work processes and rules, introduction of new equipment as well as the dropping and addition of product lines.In the same vein, Akhigbe and Ohiria (2017) assert that for organization to survive in a dynamic and competitive business environment, it depends on the effectiveness of the organization in learning how to adapt to the environment, as well as how to efficiently exercise dynamic capability on its resources. Therefore, by implication, adaptability reflect on some aspects of an organization such as: the leadership and decision making structures, knowledge and information flow as well as the 
degree of innovation, creativity and flexibility that the organization promotes or tolerates(Pollock,2016).

Situation Awareness: The challenges of a new class of technology stimulated interest in the area of situation awareness in the mid-1980's, and is required for the effective performance of tasks by individuals (Endsley and Garland,2000).Situation awareness involves the ability of an organization to monitor what is going on around the environment where they carry out their business, as well as understanding the value of such information to them in the present circumstances and later on (Endsley, Bolte and Jones, 2003). Situational awareness is usually applied in operational situations, as it was initially linked with the military where pilots are required to understand, absorb and take action on large volumes of information in order to perform their roles effectively (Endsley, 1995). Its importance cannot be overemphasized, as it empowers the organization to know how its environment and the individuals in it impact their activities. Moreover, Turner (1976) states that creating awareness and understanding of the situation as well as its potential consequences could prevent the accumulation of unobserved events.

\section{Employee Engagement and Organizational Survival}

Though there is paucity of researches conducted on employee engagementand organizational survival. Management literature shows that employee engagement has organizational outcomes on employee performance, job satisfaction, organizational effectiveness, organizational success, profitability, competitive advantage, productivity, innovation, retention, as well as dynamic work results, and these lead to sustainability and survival of an organization(Hartnell, Ou and Kinicki, 2011; Markos and Sridevi ,2010 ; Lee and Yu, 2004).Consequently, without committed and dedicated employees, an organization cannot achieve competitive advantage. When these organizational outcomes are achieved through engaged employees, the organization is said to have achieved survival.

Falola, Salau, Olokundun, Oyafunke-Omoniyi, Ayodotun, Ibidunni and Oludayo (2018) carried out a study on employees' intrapreneurial engagement initiatives and its influence on organizationalsurvival. The study showed that fostering employees' intrapreneurial engagement has positive significant implications on organizational survival. This submits that employees' empowerment, involvement, autonomy, relationships and reward system have significant effects on organizational survival.Thus, employee engagement predicts organizational survival.

\section{Empowerment and Organizational Survival}

According to Ghosh (2013), empowerment is depicted as the degree of freedom and accountability given to employees in taking decisions about their job without referring or getting approval from their supervisor.Employee empowerment aids infostering innovationand remains one of the strategies that organizations use to drive innovative idea that nurture creative capabilities (Lee, Hwang and Choi, 2012). Elnaga and Imran (2014) opined that organizations that engage its workforces are bound to get the best out of them, which will constantly generate innovative ideas and sense of duty that will definitely affect the execution of task. On the other hand, Ongori and Shunda (2008) assert that with the advent of globalization, it is imperative for organization to empower their employees in order to keep abreast of changes, as well as adapt adequately to the macro-environment.

Additionally, the outcome of their study revealed that employee empowerment is indispensable in helping organizations to respond quickly to any environmental changes, as well as reduction in employee turnover intentions.Sharma and Kaur (2011) examined workplace empowerment and organizational effectiveness in the Indian banking sector adopting competing value framework model. The finding of the study showed that employees of the public sector banks perceive themselves to be more empowered than the private sector employees. Consequently, empowerment makes employees to be motivated and passionate in making use of their unique competencies and creativity in ensuring the survival of organization. Moreover, studies showed that empowerment has various outcomes on organization such as: achievement of success, employee performance, job satisfaction (Meyerson and Dewettinck, 2012; Raza, Mahmood, Owais and Raza, 2015).

\section{Participation and Organizational Survival}

Participation is a process by which employees are involved in the organizational decision making in their workplace. The employees not just act on order but take part in decisions affecting their job.Employee participation in decision making about their job is considered as part of a high- involvement work processes, which aimed at enhancing the degree of exercising discretion and acceptance of responsibility (Boxall and Mackay, 2014).They further posit that higher involvement is a fundamental factor that predicts higher job satisfaction and improved work-life balance.According to Davis and Newstrom (1977), participation entails mental and emotional involvement of people that result to outcomes for both employees and the organization. For the employees, it leads to self-esteem and less stress, whilethe organization achieves higher output and better quality service.In the view of Azadehdel, Chegini and Delshad (2013), employee participation brings about job competencies and job autonomy, and is closely associated with quality service and job satisfaction. Furthermore, it aids in the enhancement of employee skills, provides effective services, stimulates information sharing, problem solving, as well as the generation of new ideas for employees.

According to Irawanto (2015), the ability of any organizations to involve employees in the decision making process, will enhance their creative thought. When employees are allowed to take decision in an organization, they feel valued, secured and communicates freely with their peers without limits and formal courses of action. This spurs them to go beyond and above the job demands to ensure that the organization achieve its goals.Erengwa, Nwuche and Anyanwu (2017) carried out a study on employee 
participation and organizational survival in selected manufacturing firms in Port Harcourt, Nigeria. The result of their findings revealed that team work and information sharing have impact on organizational innovation and adaptability in the manufacturing firms that were studied. The study concluded that employee participation has a significant relationship with organizational survival. Therefore, human element is continuously regarded as one of the factors affecting the survival, as well as the great asset for any organization to achieve its goals.

\section{Teamwork and Organizational Survival}

Teamwork plays an important role in the accomplishment of tasks, aids in reducing organizational hierarchy and increases the involvement of employees.Thus, when employees have the support and cooperation of their colleagues, they will share innovative ideas, accomplish more tasks, and proffer creative solutions to complex problems experienced in their organization. According to Ancona and Caldwell (1992), organization relies on teams for the development of innovative products and services, as well as to achieve survival.Harvey, Novicevic and Garrison (2004) opined that for an organization to survive in a competitive global environment is contingent on its capability to manage dynamic and adaptive teams. This is necessitated because teamwork entails cooperative environment where two or more people work together to achieve common goals by sharing knowledge and skills. From the perspective of Castka, Bamber, Sharp and Belohoubek (2001), effective teamwork enhances productivity, efficiency, creativity and performance, as well as employee satisfaction.

Reasoning in the same line of thought, Burke, Stagl, Salas, Pierce and Kendall (2006) posit that adaptation to unanticipated events can be managed by teams. This is because team members work cooperatively and dynamically, as such have variety of capacities, experiences and networks to depend on when change occurs in organization. They further posit that team learning, team innovation and team performance management are related, and thus have effect on team adaptation. The study by Hoegel and Gemuende (2001) revealed that teamwork quality has strong relationship with the personal success (job satisfaction and learning) of team members. Moreover, Fay, Shipton, West and Patterson (2015) investigated teamwork and organizational innovation with HRM context playing a moderating role. Their finding submitted that the extensive utilization of teamwork, leads to higher level of organizational innovation, and thus, is dependent on production teams, as well as the general nature of the HRM frameworks that exist in the companies.

\section{The Moderating Role of Organizational Culture between Employee Engagement and Organizational Survival}

Organization is a social system that is made up of people with diverse backgrounds, who work interdependently and cooperatively to achieve their goals. Thus, organizational culture serves as the bridge in bringing these individuals with different values, perception, ambition and principles together. Organizational culture could be positive or negative. Organizations with a positive culture reward their employees, and create a conductive environment where employees develop, grow and operate at their full potential (Robbins and Judge 2012). Thus, culture of an organization affects the way the employees behave, think, act, feel and perform their assigned roles, and involves the combination of values, beliefs and norms (Schein, 2011).Culture is very paramount in the survival of every organization. Therefore, the ability of organization to foster creativity and innovation depends on organizational culture. From the perspective of Nair and Gopal (2011), an organization that nurture innovation and culture, must gradually provide facilities, incentives, conducive work environment coupled with effective leadership. Effective leadership influences followers' ability to generate new ideas and have passion in what they do.

Hofstede (2003) describes culture as values and applications of an organization which differentiates it from others. Accordingly, Gong, Huang and Farh (2009) assert that the ability of the followers or subordinates to be innovative is based on the leader's exhibition of empathy, consideration, and support, which help them to work efficiently and effectively. This corroborates with the view of Alarcon, Lyons and Tartaglia (2010). They posit that engagement of the workforce is appraised at an individual level taking into cognizance that individual commitment levels are affected by the organization's leadership and culture among different elements. Organizational culture is very unique to an organization, hence, regarded as the lifeblood of any organization.A supportive culture spurs employees to be innovative and work towards the achievement of organizational goals (Van Allen, 2013).

According to Sok, Blomme and Tromp (2014), employees that work in an organization with supportive culture enjoy work-life balance, experience reduction in negative work-home spill overs. Furthermore, the organization provides flexible work home arrangements, which lead to the attraction and retaining of high quality employees. Thus, organizational culture is the most essential variable that influences the organizational performance and subsequently survival.Organizational culture has positive outcomes on innovation capability (Yesil and Kaya, 2012), product innovation (Valencia, Valle and Jiménez, 2010), and corporate performance (Oparanma, 2010). Yesil and Kaya (2012) carried out a study on the role of organizational culture on innovation capability. Their result indicated that adhocracy culture dimension positively affects innovation capability of the firms. Also, study carried out by Oparanma (2010) showed that organizational culture has positive effect on performance.

\section{CONCLUSION}

The paper critically reviewed employee engagement and organizational survival. The review has established that employee engagement influences organizational survival. It also revealed that there is no universally agreed definition of employee engagement, as it has been defined differently by 
scholars and practitioners. This lack of unified definition has affected its measurement.Employee engagement is at the heart of the employment relationship. It is about what people do and how they behave in their roles and what makes them act in ways that aligns their objectives with that of the organization. When an organization has a positive and supportive culture that embraces employee engagement, the employees put in their best and go beyond their job task to ensure the organization becomes successful. Therefore, the two key elements in employee engagement are commitment and discretionary effort. Employee engagement has various outcomes such as effectiveness, profitability, productivity, improved customer service, job satisfaction and improvement in the well-being of the employee. Consequently, when an organization achieves the above outcomes, it will survive and achieve long-term sustainability. Thus, employee engagement aids organization in achieving competitive advantage.

\section{RECOMMENDATIONS}

Based on the above conclusion, we recommend that managers should keep their employees engaged in order to achieve their goals, as well as to reduce cost of recruiting new employees for the same job. Moreover, since organizational culture affects employee engagement, management of organizations should ensure that employee engagement is crafted into their strategic intent in order to have an engaged employee that will help the organization achieve its goals. Furthermore, effective leadership plays a prominent role in fostering engagement; therefore leaders should be empathetic andsupport any innovative ideas emanating from the employees in order to effect a positive change. Lastly, organization can utilize the exit interview with departing employees to determine the level of engagement in the organization if properly handled

\section{REFERENCES}

[1] Abraham, S. (2012). Job satisfaction as an antecedent to employee engagement. SIES Journal of Management, 8(2), 27-36.

[2] Agboola, A. A., \& Salawu, R. O. (2011). Managing deviant behavior and resistance to change. International Journal of Business and Management. 6(1), 235-242.

[3] Aguinis, H. (2013). Performance management. Retrieved on $20^{\text {th }}$ October, 2019 from https://www.ebsglobal.net/EBS/media/EBS/PDFs/Performance-Mana gement-Course-Taster.pdf

[4] AIHR Analytics (2009). Measuring employee engagement the right way. Retrieved on $21^{\text {st }}$ November, 2019 from https://www.analyticsinhr.com/blog/measuring-employee-engagement I

[5] Akhigbe, O. J \& Ohiria, S. I. (2017). Workforce diversity and organizational survival of private hospitals in Nigeria, IOSR Journal of Business and Management, 19(7), 34-41.

[6] Alarcon, G., Lyons, J. B. \& Tartaglia, F. (2010). Understanding predictors of engagement within the military. Military Psychology, 22(1), 301-310.

[7] Albercht, S. L., Bakker, A. B., Gruman, J. A., Macey, W. H., \& Saks, A. M. (2015). Employee engagement, human resource management practices and competitive advantage: An integrated approach. Journal of Organizational Effectiveness: People and Performance, 2(1), 7-35.
[8] Amabile, T.M. (1997). Motivating creativity in organizations: On doing what you love and loving what you do. California Management Review, 40(1), 39-58.

[9] Ancona, D. G., \& Caldwell, D.F. (1992). Bridging the boundary: External activity and performance in organizational teams. Administrative Science Quarterly, 37(4), 634-665.

[10] Azadehdel, M. R., Chegini, M. G., \&Delshad, C. M. (2013). Effective employees participation and organizational outcomes. Arabian Journal of Business and Management Review Nigerian Chapter, 1(9), 1-7.

[11] Baird, K. \& Wang, H. (2010). Employee empowerment: Extent of adoption and influential factors. Personnel Review, 39( 5), 574-599.

[12] Bakker, A. B., Albrecht, S.L. \& Leiter, M.P. (2011). Key questions regarding work engagement.European Journal of Work and Organizational Psychology, 20(1), 4- 28.

[13] Bedwell, W. L., Wildman, J. L., DiazGranados, D., Salazar, M., Kramer, W. S., \& Salas, E. (2012). Collaboration at work: An integrative multilevel conceptualization. Human Resource Management Review, 22, 128-145.

[14] Blau, P. (1964). Power and exchange in social life. New York: John Wiley \& Sons.

[15] Boxall, P., \& Macky, K. (2014). High-involvement work processes, work intensification and employee well-being. Work, employment and society, 28(6), 963-984.

[16] Bradley, B. H., Postlethwaite, B. E., Klotz, A. C., Hamdani, M. R., \& Brown, K.G. (2011). Reaping the benefits of task conflict in teams: The critical role of team psychological safety climate. Journal of Applied Psychology, 97(1), 151-158.

[17] Burke, C. S., Stagl, K. C., Salas, E., Pierce, L., \& Kendall, D. (2006) Understanding team adaptation: A conceptual analysis and model. Journal of Applied Psychology, 91(6), 1189-1207.

[18] Burke, C. S., Wilson, K. A., \& Salas, S. (2003). Teamwork at 35,000 feet: Enhancing safety through team training. Human Factors and Aerospace Safety, 3(4), 287-312.

[19] Cadwallader, S., Jarvis, C. B., Bitner, M. J., \& Ostrom, A. L. (2010) Frontline employee motivation to participate in service innovation implementation. Journal of the Academy of Marketing Science, 38 (2), 219-239.

[20] Castka, P., Bamber, C. J., Sharp, J. M., \& Belohoubek, P. (2001). Factors affecting successful implementation of high performance teams. Team Performance Management: An International Journal, 7(8), 123-134.

[21] Christian, M.S., Garza, A.S. \& Slaughter, J.E. (2011). Work engagement: A quantitative review and test of its relations with task and contextual performance, Personnel Psychology, 64(1), 89-136.

[22] CIPM (2018). Advanced human resource management 2, professional examination II study pack ( $3^{\text {rd }}$ ed.). Lagos: CIPM House.

[23] Cohen, W. M. \& Levinthal, D. A. (1990). Absorptive capacity: A new perspective on learning and innovation. Administrative Science Quarterly, 35(1), 128-152.

[24] Colquitt, J. A., Conlon, D. E., Wesson, M. J., Porter, C. O. L. H., \& Ng, K. Y. (2001). Justice at the millennium: A meta-analytic review of 25 years of organizational justice research. Journal of Applied Psychology, 86 (3), 425 - 445.

[25] Connaughton, S. L., \& Daly, J. A. (2004). Identification with leader: A comparison of perceptions of identification among geographically dispersed and co-located teams. Corporate Communication: An International Journal, 9(2), 89-103.

[26] Cotton, J. L., Vollrath, D. A., Froggatt, K. L., Lengnick-Hall, M. L., \& Jennings, K. R. (1988). Employee participation: Diverse forms and different outcomes. Academy of Management review, 13(1), 8-22.

[27] Daft, R. L. (2001). Organization theory and design (7th ed.). Florence KY, United States: South-Western College Publishing. 


\section{Employee Engagement and Organizational Survival}

[28] Davis, K., \& Newstrom, J. W. (1997). Human behaviour at work: Organizational behavior. New York: McGraw-Hill Companies.

[29] DeChurch, L. A., \& Mesmer-Magnus, J. R. (2010). The cognitive underpinnings of effective teamwork: A meta-analysis. Journal of Applied Psychology, 95(1), 32-53.

[30] Denison, D. (2007). Denison consulting model. An Hunkong: Arbor Zurich Shanghai Press.

[31] Denison, D. R. (1990). Corporate culture and organizational effectiveness. New York: John Wiley \& Sons.

[32] Ellonen, R., Blomqvist, K. \& Puumalainen, K. (2008). The role of trust in organizational innovativeness. European Journal of Innovation Management, 11(2), 160-181.

[33] Elnaga, A. A., \& Imran, A. (2014). The impact of employee empowerment on job satisfaction: Theoretical study. American Journal of Research Communication, 2(1), 13-26.

[34] Endsley, M. R. (1995). Toward a theory of situation awareness in dynamic systems. Human Factors, 37(1), 32-64.

[35] Endsley, M. R., \& Garland, D. J. (2000). Theoretical underpinnings of situation awareness: A critical review on situation awareness analysi and measurement. Mahwah, New Jersey : Lawrence Erlbaum Associates.

[36] Endsley, M. R., Bolte, B. \& Jones, D. G. (2003). Designing for situation awareness: An approach to human-centered design. London: Taylor \& Francis Design.

[37] Erengwa, K. N., Nwuche, C. A., \& Anyanwu, S. C. (2017). Employee participation and organizational survival in selected manufacturing firms in Port Harcourt, Nigeria. International Journal of Advanced Academic Research, Social \& Management Sciences3(3), 1-10.

[38] Falola, H.O., Salau, O. P., Olokundun, M. O., Oyafunke-Omoniyi, C O., Ayodotun, S., Ibidunni, A. S. \& Oludayo, O. A.(2018) Employees' intrapreneurial engagement initiatives and its influence on organizational survival. Business: Theory and Practice, 19(1), 9-16.

[39] Fay, D., Shipton, H., West, M. A., \& Patterson, M. (2015). Teamwork and organizational innovation: The moderating role of the HRM context. Creativity and Innovation Management, 24(2), 261-277.

[40] Fleming, R. S. (2012). Ensuring organizational resilience in times of crisis. Journal of Global Business, 6 (1), 31-34.

[41] Frank, F., Finnegan, R. \& Taylor, C. (2004). The race for talent: Retaining and engaging workers in the 21st century. Human Resource Planning, 27 (3), $12-26$

[42] Gallup (2006). Gallup study: Engaged employees inspire company innovation: national survey finds that passionate workers are most likely to drive organizations forward'. Retrieved on $22^{\text {nd }}$ November,2019

https://www.gallup.com/topic/all gbj headlines.aspx

[43] Ghosh, A. K. (2013). Employee empowerment: A strategic tool to obtain sustainable competitive advantage. International Journal of Management, 30 (3), 95-107.

[44] Gong, Y., Huang, J. C., \& Farh, J. L. (2009). Employee learning orientation, transformational leadership, and employee creativity: The mediating role of employee creative self-efficacy. Academy of management Journal, 52(4), 765-778.

[45] Gross, B. (1968).Organizations and their managing. New York: The free Press.

[46] Guest, D.E. (2014). Employee engagement: A skeptical analysis, Journal of Organizational Effectiveness: People and Performance, 1(1), 141-156

[47] Hackman, J. R., \& Wageman, R. (2005). A theory ofteam coaching. Academy of Management Review, 30(2), 269-287.
[48] Halbesleben, J.R.B. (2010). A meta-analysis of work engagement Relationships with burnout, demands, resources and consequences, in Bakker, A.B. and Leiter, M.P. (Eds), Work Engagement: A Handbook of Essential Theory and Research, Psychology Press, New York, NY, 102-117.

[49] Hartnell, C. A., Ou, A. Y., \& Kinicki, A. (2011). Organizational culture and organizational effectiveness: A meta-analytic investigation of the competing values framework's theoretical suppositions. Journal of Applied Psychology, 96(4), 677-694

[50] Harvey, M., Novicevic, M., \& Garrison, G. (2004). Challenges to staffing global virtual teams. Human Resource Management Review 14(3), 275-294.

[51] Hertel, G., Konradt, U., \& Orlikowski, B. (2004). Managing distance by interdependence: Goal setting, task interdependence, and team-based rewards in virtual teams. European Journal of Work and Organizational Psychology. 13(1), 1-28.

[52] Hoegel, M., \&Gemuende, H. G. (2001). Teamwork quality and the success of innovative projects: A theoretical concept and empirica evidence. Organization Science 12(4), 435-449.

[53] Hofstede, G. (2003).Cultures and organizations: Intercultural cooperation and Its Importance for survival: Software of the Mind. London-UK: Profile Books Ltd.

[54] HR Exchange Network (2018). Employee engagement on the rise Gallup survey shows increase from 2015 . Retrieved on $22^{\text {nd }}$ November, 2019 from https://www.hrexchangenetwork.com/employee-engagement/articles/e mployee-engagement-on-the-rise-gallup-survey

[55] Huber, G. P. (2011). Organizations: Theory, design, future. In S. Zedek (Ed.), APA handbook of industrial and organizational psychology (p.V1). Washington, DC: American Psychological Association.

[56] Hult, G. T. M., Hurley, R. F., \& Knight, G. A. (2004). Innovativeness: Its antecedents and impact on business performance. Industrial Marketing Management, 33(5), 429-38.

[57] Humphrey, S. E., Morgeson, F. P., \& Mannor, M. J. (2009).Developing a theory of the strategic core of teams: A role composition model of team performance. Journal of Applied Physiology, 94(1), 48-61.

[58] Hunjra, A. I., Ul Haq, N., Akbar, S. W., \& Yousaf, M. (2011). Impact of employee empowerment on job satisfaction: an empirical analysis of Pakistani service industry. Interdisciplinary Journal of Contemporary Research in Business, 2(11), 680-685.

[59] Irawanto, D. W. (2015). Employee participation in decision-making: Evidence from a state-owned.Management, 20(1), 159-172.

[60] Jaja, S. A., Gabriel, J. M. O., \& Wobodo, C. C. (2019). Organizational isomorphism: The quest for survival. Noble International Journal of Business and Management Research, 3(5), 86- 94.

[61] Kahn, W.A. (1990). Psychological conditions of personal engagement and disengagement at work. Academy of Management Journal, 33(4), $692-724$

[62] Kazimoto, P. (2016). Employee engagement and organizational performance of retails enterprises. American Journal of Industrial and Business Management, 2 6(1), 516-525.

[63] Kim, S. (2002). Participative management and job satisfaction Lessons for management leadership. Public Administration Review, 62 (2), 231-241

[64] Kortmann, S., Gelhard, C., Zimmermann, C., \& Piller, F. (2014) Linking strategic flexibility and operational efficiency: The mediating role of ambidextrous operational capabilities. Journal of Operations Management, 32(1), 475-490.

[65] Laila, U., Iqbal, S., \& Rasheed, M. (2019). Abusive supervision and workplace deviance: The moderating role of power distance. Pakistan Journal of Commerce and Social Sciences (PJCSS), 13(2), 334-357. 
[66] Lee (2006). Management succession planning and corporate survival in Nigeria: A study of banks in Port Harcourt. European Journal of Business and Management, 7(27), 153- 176.

[67] Lee, S. M., Hwang, T., \& Choi, D. (2012). Open innovation in the public sector of leading countries. Management Decision, 50 (1) 147-162.Lee, S. K. J., \& Yu, K. (2004). Corporate culture and organizational performance. Journal of Managerial Psychology, 19(4), 340359 .

[68] LePine, J. A., Piccolo, R. F., Jackson, C. L., Mathieu, J. E., \& Saul, J. R. (2008). A meta-analysis of teamwork processes: Tests of a multidimensional model and relationships with team effectiveness criteria. Personnel Psychology, 61(2), 273-307.

[69] Lumpkin, G.T. \& Dess, G. G. (1996). Clarifying the entrepreneurial orientation construct and linking it to performance. Academy of Management Review, 21(1), 135-172.

[70] Macey, W. H., Schneider, B., Barbera, K.M. \& Young, S.A. (2009). Employee engagement: Tools for analysis, practice, and competitive advantage. Hoboken, New Jersey: Wiley-Blackwell, Malden, WA.

[71] Manu, F.A. (1992). Innovation orientation, environment and performance: A comparison of U.S. and European markets. Journal of International Business Studies, 23(2), 333-359.

[72] Markides, C. (1998). Strategic innovation in established firms. In M. Mazzucatto (Ed.), A reader: Strategy for business. England: Sage Publications Ltd.

[73] Markos, S., \& Sridevi, M.S. (2010) Employee engagement: The key to improving performance. International journal of business and management, 5(12), 89-96.

[74] Marks, M. A., Zaccaro, S. J., \& Mathieu, J. E. (2000). Performance implications of leader briefings and team interaction training for team adaptation to novel environments. Journal of Applied Psychology, 85(6), 971-986.

[75] Mathieu, J. E., Maynard, M. T., Rapp, T., \& Gilson, L. L. (2008). Team effectiveness 1997-2007: A review of recent advancements and a glimpse into the future. Journal of Management, 34(3), 410-476.

[76] Menguc, B., \& Auh, S. (2006). Creating a firm-level dynamic capability through capitalizing on market orientation and innovativeness. Journal of the academy of marketing science, 34(1) 63-73.

[77] Meyerson, G., \& Dewettinck, B. (2012). Effect of empowerment on employees performance. Advanced Research in Economic and Management Sciences, 2(1), 40-46.

[78] Mishra, K., Boynton, L., \& Mishra, A. (2014). Driving employee engagement: The expanded role of internal communications International Journal of Business Communication, 51(2) 183-202.

[79] Mitchell, T. R. (1973). Motivation and participation: Integration.Academy of management Journal, 16(1), 670-679.

[80] Mone, E. M., \& London, M. (2010). Employee engagement: Through effective performance management. A practical guide for managers. New York : Routledge Press.

[81] Morgeson, F. P., DeRue, D. S., \& Karam, E. P. (2010). Leadership in teams: A functional approach to understanding leadership structures and processes. Journal of Management, 36(1), 5-39.

[82] Nair, K., \& Gopal, R. (2011). Advocating different paradigms: Relevance of workplace creativity. SIES Journal of Management, 7(2) 142-150.

[83] Namrita, K. \& Yoginder, S.V. (2017). Organizational culture and employee engagement: An Interrelationship study in hospitality industry of Himachal Pradesh. International Journal of Human Resource Management and Research, 7(3), 13-22.
[84] Noah, Y. (2008). A study of worker participation in management decision making within selected establishments in Lagos, Nigeria. Journal of Social Science, 17 (1), 31-39.

[85] Olughor, R.J. \& Oke, M. A. (2014). The relationship between organizational survival and employee mental ability. International Journal of Business and Social Science, 5, 6(1), 205-212.

[86] Ongori, H., \& Shunda, J. P.W (2008). Managing behind the scenes: Employee empowerment. The International Journal of Applied Economics and finance, 2(2), 84- 94.

[87] Oparanma, A.O. (2010).The organizational culture and corporate perf ormance in Nigeria.

International Journal of African Studies, 3(2), 34-40.

[88] Osborne, S., \& Hammoud, M. (2017). Effective employee engagement in the workplace. International Journal of Applied Management and Technology, 16, (1), 50-67.

[89] Pastor, J. (1996). Empowerment: What it is and what it is not Empowerment in Organizations, 4( 2), 5-7. Retrieved on $21^{\text {st }}$ November, 2019 from https://www.emerald.com/insight/content/doi/10.1108/096848996101 18028/full/html

[90] Pepra-Mensah, J., \& Kyeremeh, E. A. (2018). Organizational culture A catalyst for employee engagement in the Ghanaian public sector Global Journal of Human Resource Management, 6(3), 11-28.

[91] Pillay, E. \& Singh, S. (2014). The Impact of employee engagement on organizational performance: A case of an insurance brokerage company in Gauteng. IOSR Journal of Business and Management, 20(6), 66-76.

[92] Pollock, K. (2016). Resilient organization or mock bureaucracy: Is your organization "crisis-prepared" or "crisis-prone". Emergency planning college occasional papers new series number 16, March 2016.Retrieved on $28^{\text {th }} \quad$ March, 2019 from https://www.epcresilience.com/EPC/media/MediaLibrary/Knowledge \%20Hub\%20Documents/J\%20Thinkpieces/Occ16-Paper-Resilient-orMock.

[93] Raza, H., Mahmood, J., Owais, M., \& Raza, A. (2015). Impact of employee empowerment on job satisfaction of employees in corporate banking sector employees of Pakistan. Journal of Applied Environmental and Biological Sciences, 5(2), 1-7.

[94] Reilly, R. (2014). Five ways to improve employee engagement now. Retrieved on $22^{\text {nd }} \quad$ November, 2019 from https://www.gallup.com/workplace/231581/five-ways-improve-emplo yee-engagement.aspx

[95] Richman, A. (2006). Everyone wants an engaged workforce how can you create it? Workspan, 49(1), 36-39.

[96] Robbins, S., \& Judge, T. (2012). Essentials of organizational behavior $\left(11^{\text {th }}\right.$ ed.) Upper Saddle River, New Jersey : Pearson Prentice Hall.

[97] Robinson, D., Perryman,S., \& Hayday, S. (2004). Thedriversofemployeeengagement- Institute for employment studies, Brighton. Retrieved on $22^{\text {nd }}$ November, 2019 from https://www.employment-studies.co.uk/system/files/resources/files/40 $\underline{8 . p d f}$

[98] Saif, N. I., \& Saleh, A. S. (2013). Psychological empowerment and job satisfaction in Jordanian hospitals. International Journal of Humanities and Social Science, 3(16), 250-257.

[99] Saks, A. (2006). Antecedents and consequences of employee engagement. Journal of Managerial Psychology, 21 (7), 600 - 619.

[100] Salas, E., Dickinson, T. L., Converse, S. A., \& Tannenbaum, S. I (1992). Toward an understanding of team performance and training. In R. W. Swezey \& E. Salas (Eds.), Teams: Their training and performance (3-29). Norwood, NJ: Ablex Publishing.

[101] Salas, E., Shuffler, M., Thayer, A. Bedwell, W. \& Lazzara, H. E (2014). Understanding and improving teamwork in organizations: 


\section{Employee Engagement and Organizational Survival}

A scientifically based practical guide. Retrieved on $21^{\text {st }}$ November, 2019 from https://orpca.org/APCM/Salas et al-2014-Human Resource Manage ment\%201\%203.pdf

[102] Schaufeli, W.B., Salanova, M., González-Romá, V. \& Bakker, A.B (2002). The measurement of engagement and burnout: A two sample confirmatory factor analytic approach, Journal of Happiness Studies, 3, 71-92.

[103] Schein, E. H. (2011). Leadership and organizational culture. New York: Wiley and Bros.

[104] Senevirathna, Y. (2018). Employee participation on decision making: A review on conceptual and practice perspectives. International Journal of Advancements in Research \& Technology, 7(7), 198- 208.

[105] Sharma, M., \& Kaur, G. (2011). Workplace empowerment and organizational effectiveness: An empirical investigation of Indian banking sector. Academy of Banking Studies Journal, 10 (2), 105-120.

[106] Sheppard, J. P. (1993). Organizational survival and corporate level diversification. Journal of Financial and Strategic Decisions, 6(1), 113-132.

[107] Siddhanta, A., \& Roy, D. (2010). Employee engagement- Engaging the 21 st century workforce. Retrieved on $28^{\text {th }}$ October, 2019 from http://www.ipublishing.co.in/ajmrvol1no1/sped12011/AJMRSP1015.p df

[108] Simpson, M. (2008). Engagement at work: A review of the literature.International Journal of Nursing Studies, 46(1), 1012-1024.

[109] Slater, S. F., \& Narver, J. C. (1994). Does competitive environment moderate the market orientation-performance relationship. Journal of marketing, 58(1), 46-55.

[110] Sok, J., Blomme, R., \& Tromp, D. (2014). Positive and negative spillover from work to home: The role of organizational culture and supportive arrangements. British Journal of Management, 25(3), 456-472.

[111] Stahl, G. K., Maznevski, M. L., Voigt, A., \& Jonsen, K. (2010). Unraveling the effects of cultural diversity in teams: A meta-analysis of research on multicultural workgroups. Journal of International Business Studies, 41, 690-709.

[112] Torrington, D., Hall, L., Taylor, S., \& Atkinson, C. (2014). Human resource Management ( $9^{\text {th }}$ ed.). London: Pearson Education Limited.

[113] Turner, B.A. (1976). The organizational and inter-organizational development of disasters. Administrative Science Quarterly, 21(3), 378-397.

[114] Van Allen, S. (2012). Engagement at work: Its effects on performance continue in tough economic times: Key findings from Gallup's Q12 Meta-analysis of 1.4 million employees, Gallup, Inc. Retrieved on $21^{\text {st }}$ November,2019 from https://www.gallup.com/services/176657/engagement-work-effect-per formance-continues-tough-economic-times.aspx

[115] Valencia, J.C.N., Valle, R.S., \& Jiménez, D.J. (2010). Organizational culture as determinant of product innovation. European Journal of Innovation Management, 13(4), 466-480.

[116] Vroom, V. H. (1974). Decision-making and the leadership process. Journal of Contemporary Business, 3 (4), 47-64.

[117] Wang, C. L. \& Ahmed, P.K. (2004). The development and validation of the organizational innovativeness construct using confirmatory factor analysis. European Journal of Innovation Management, 7(4), 303-313.

[118] Wood, S., \& De Menezes, L. M. (2011). High involvement management, high-performance work systems and well-being. The International Journal of Human Resource Management, 22 (7), 1586-1610.
[119] Yeşil, S., \& Kaya, A. (2012). The role of organizational culture on innovation capability: An empirical study.International Journal of Information Technology and Business Management, 6(1), 11-25. 